\title{
International Conference on Islamic Economics and Economies of the OIC Countries 2009
}

Amidst the current global interest in searching for possible solutions to the current financial difficulties, the International Conference on Islamic Economics and Economies of the OIC Countries 2009 (ICIE2009) held in Kuala Lumpur, Malaysia, was indeed timely. Held during 28-29 April 2009 , it provided a platform to promote an intellectual discourse designed to evaluate the current state of the discipline's various subdisciplines as regards its practical applications. The Department of Economics of the International Islamic University Malaysia (IIUM) and the Islamic Research and Training Institute of the Islamic Development Bank (IDB), adopting a proactive approach, brought together scholars and industry players from across the world to analyze how to enhance the theoretical and applied aspects of Islamic economics, banking, and economic cooperation among Muslim countries. This event also marked an important date: the IIUM is celebrating its twenty-fifth-year anniversary, while the OIC is celebrating its fortieth. 
The conference featured two keynote addresses. The first one, Ekmeleddin Ihsanoglu's (secretary general, OIC) "Enhancing Economic Cooperation among Muslim Countries: The Role of the OIC," essentially highlighted the issues and challenges facing the ummah's greater economic integration. While it is encouraging to note that the necessary elements for greater integration are already in place, a concerted effort toward realizing this goal leaves a great deal to be desired. He has high hopes, however, that scholars will continue to find ways of bringing this envisioned economic integration closer to reality so that it can benefit the countries involved and, one day, achieve the ultimate objective: bettering the ummah. The second keynote address, Abbas Mirakhor's (former executive director, International Monetary Fund) "Islamic Economics and Finance: An Institutional Perspective," outlined the ideals of Islamic economics and how it can be a viable alternative to the conventional economic system.

The conference also featured two plenary sessions that enabled more focused and deeper discussions on topics that are highly relevant in the context of the Muslim world. The first one, presented by Savas Alpay (director general, the Statistical, Economic, and Social Research and Training Center for Islamic Countries), deliberated upon "The OIC Countries: Performance, Issues, and Challenges." The second one, presented by Amadou Cire Sall (The Islamic Center for Development of Trade, OIC) and J. Jayasiri (senior director, FTA Policy and Negotiations Coordinator, the Ministry of International Trade and Industry, Malaysia) discussed "The Role of Regional Groupings in Promoting Trade and Development of Muslim Countries."

More than 150 working papers were submitted, implying the high interest in this particular discipline and the economies of the OIC countries, as well as the extensive amount of research that has been undertaken in these areas. Out of these, only eighty were selected for oral presentation in the events' four parallel sessions. The mere presence of the speakers, who came from Australia, Bangladesh, Brunei, Canada, India, Indonesia, Iran, Kuwait, Oman, Pakistan, Singapore, South Korea, Turkey, UAE, Uganda, Great Britain, and the United States, reflected the fact that Islamic economics and the economies of the OIC countries have made in-roads into universities and research institutes worldwide. The papers were categorized into four major themes: Islamic economics, Islamic banking and finance, economies of the OIC countries, and economic cooperation among the OIC countries. It is encouraging to note that the papers not only evaluated past performance, but also made a continuous assessment of the discipline's progress and the 
extent of its development and applications, particularly in Muslim countries. More importantly, most of the papers charted out the possible directions to be followed in the future at both the theoretical and policy levels.

Three presentations received the Best Paper award during the closing ceremony. The first one, "Rational Speculative Bubbles in the OIC Stock Markets" by Jung-Suk Yu and Kabir Hassan (Samsung Economic Research Institute/University of New Orleans), examined the possibility of speculative bubbles in the OIC stock markets by employing several tests, among them the fractional bubble test and the duration dependent test. The authors found no evidence of speculative bubbles in the OIC stock markets. The second paper, "Towards an Islamic Common Market: Are OIC Countries Heading in the Right Direction?" by Ruzita Mohd Amin and Zarinah Hamid (International Islamic University Malaysia), investigated the existing trade potential among the OIC countries and the specific sectors in which tariff reductions can be undertaken in five out of the seventeen OIC countries that have agreed to participate in the Trade Preferential System. The third paper, "Divergence between Aspirations and Realities of Islamic Economics: A Political Economy Approach to Bridging the Divide" by Nazim Zaman and Mehmet Asutay (Durham University), attempted to identify the underlying causes of the failure to implement Islamic socioeconomic theory in reality. Subsequently, they presented an integrated model of the Islamic development paradigm with political economy sophistication in an effort to link economic theory with political reality.

The two-day deliberations opened new avenues for greater improvements and refinements in Islamic economics and research on the economies of the OIC countries. This conference marked the beginning of an active synergy in the IIUM-IDB-OIC collaboration to expedite the effort to better the ummah through research-based policy formulations and implementation. The combination of resources among these three critical institutions, all of which share a common objective, undoubtedly presents all of the required ingredients for success. The IIUM will contribute in terms of intellectual input and personnel requirements; the IDB will fulfill the much-needed financial assistance to enable quality research activities to be undertaken; and the OIC will provide the infrastructure and mechanism needed to apply, in a practical manner, the research output in Muslim countries.

Salina H. Kassim

Assistant Professor, Department of Economics The International Islamic University Malaysia, Kuala Lumpur 